\title{
The implementation of reading corner and teacher modeling in Indonesian learning through psycholinguistic approach
}

\author{
Khoiriyatun Ni'mah \\ LP Ma'arif Mangunsari Salatiga \\ khoirailma@gmail.com
}

DOI: 10.18326/mudarrisa.v10i1.47-72

\begin{abstract}
Reading Corner and teacher modeling are strategies to improve students' learning process through habit of utilizing classroom corner as a place to read with a teacher as direct model in the activity. The purposes of this research are: 1) implementing innovative learning activities with non monotonous classroom atmosphere; 2) creating interactive and interesting learning process; 3) enhancing students' reading motivation, and; 4) improving students' academic achievement. This research is a qualitative descriptive research used to describe and analyze phenomenon and real condition in the field through psycholinguistic approach to support language learning process in order to improve students' motivation to read, write, listen and talk, which has implication to create a good teaching learning process, curriculum which is appropriate with the changes of human dimension, appropriate lesson plan, materials and syllabus for students, as well as performing appropriate assessment. Research findings showed that: 1) students have high motivation and awareness to read; 2) creating conducive learning atmosphere for students to learn; 3) the way students learn is open not solely rely on transfer of knowledge from teachers; 4) the emergence of interest in asking and discussing the information obtained from reading; 5) the emergence of students' courage in conveying the idea of the results of understanding from learning; 6) the knowledge is developed; 7) students' vocabulary mastery is getting better; 8 ) increasing the academic ability of students.
\end{abstract}

Keywords: reading corner, teacher modeling, psycholinguistics 


\section{INTRODUCTION}

Indonesian is a compulsory subject in every formal school education, including basic education level or commonly known as Madrasa Ibtidaiya (MI) or Primary School (SD). In the world of education, language skill is the capital for students to explore the knowledge that will be developed in formal education, especially the fourth grade students as the capital to face national exam in grade VI. The phenomenon of language is closely related to human life. Language is the study of linguistics which is learned as a language that includes several components: phonology, morphology, syntax, and semantics. While using language is a study of psycholinguistics, which examines human activities in acquiring, receiving and producing language, no human activity without the presence of language (Abdul Chaer \& Leonie Agustina, 2010: 14).

Indonesian has function as: 1) symbol of nationality; 2) symbol of national identity; 3) unifying means of different societies with different social, cultural, and language backgrounds; 4) intercultural or regional communication means. Meanwhile, the position of Indonesian as the language of the country has function as: 1) official language of the state; 2) official language instruction in education world, and; 3) official language in the national level of relationship for the interest of planning and implementation of development and modern technology (Masnur Muslih, 2009: 108).

Indonesian, like other languages, has four components that should be mastered by learners, namely listening, speaking, reading and writing 
(Permendiknas No. 22, 2006). Those four components have competence standard and basic competence separately. However, in the implementation of learning the four skills are always integrated each other in every language learning, the thing that distinguishes is the emphasis on one of language skills in accordance with competence standard and basic competence that have been determined.

According to Langi, A. Tahir, M. \& Idris (2017: 89-90) in more complex society like present time, language skill is very important and needs to be mastered by students, especially reading skill. First, when students are in the process of studying in upper class, reading skill is required for studying each subject. Second, students live in a community outside school, and they need reading skill, for example reading newspapers, magazines, menus in restaurants, film texts, etc. Based on the above phenomena, the writer considers that some information that develops in the community encourages the teachers to prepare reading text that contains information relevant to learners. In addition, it is necessary for teacher to motivate learners so that they get used to and enjoy reading activities. To train and inculcate reading habits is not easy, but it is necessary to accustom and learn to read as early as possible, especially at the level of elementary school in the upper class.

Reading is the activity of seeing and understanding the contents of what is written either verbally or just in the heart (Sutarimah Ampuni, 1998). Besides, reading is also interpreted as spelling or pronouncing what is written, recited, predicted and guessed (Endang Sri Sulasih, 2016). 


\section{Mudarrisa: Jurnal Kajian Pendidikan Islam, Vol. 10, No. 1, 2018}

Reading is process of gaining information critically and creatively for the purpose of understanding reading text, as well as an assessment of the circumstances, values, and impacts of reading (Sandi Farboy, 2009). Reading is a process that involves physical and mental activity. One of physical activities in reading is moving the eyes along the lines of writing in a reading text, and mental activity can ensure the acquisition of maximum understanding. Furthermore, reading is an activity of thinking to understand writing (Nugroho, A. H., Puspitasari, R. \& Puspitasari, E., 2016).

To carry out this activity, there must be innovation and a new way to get reading learning process expected by students, one of them is by applying the learning model that makes reading learning process more interesting. Likewise writing, writing skill is productive and creative activity that can be done by learners. This means that communication is using written language as the medium. The purpose of learning to write is to foster the love of students, develop students' writing skill and creativity to write better. Growing the love of writing to students is the capital to be accustomed to it. Writing skill is not gotten naturally, but through training and intensive practice.

Writing skill is one of those skills in which it has many obstacles. Students have not been able to use written language perfectly. In practice at the School, some of the various writings that must be mastered by students include general text such as narrative, descriptive, exposition, argumentative, and persuasive. Apart from that, to be able to write in 


\section{Mudarrisa: Jurnal Kajian Pendidikan Islam, Vol. 10, No. 1, 2018}

general genre, students must also be able to write in literary genres such as poetry, drama, and other creative literary works. In line with the variety of writing, writing learning should be able to guide students to the right path (Mustikowati, D. Wijayanti, E. \& Darmanto, J., 2016: 39-40).

The success of language learning will largely depend on the components involved in learning. These components include students as the subject and language learning materials learned by students. Therefore, in language learning the understanding of psycholinguistics is considered important. Through psychology, we study about students and through linguistics we study about language material. Through this interdisciplinary process, we figure out the process conducted by students when they understand the language material.

The implementation of innovative learning activities will create a conducive and effective classroom atmosphere. In this situation students will discuss, interact, and dialogue so that they are able to construct their own scientific concepts and rules, not by way of forcing or lecturing. Students also need to be familiarized with different opinion, so that they will become an intelligent and critical figure. Of course, democratically, without ignoring the rules of knowledge. In addition, teachers also need to provide reinforcement to students so that there is no wrong concept that will conflict with the values of truth itself (Batubara \& Ariani, 2018: 447).

In learning Indonesian teachers are expected to provide learning process with various components of language skills. Competence provides learning related to various factors, including formulating indicators and 


\section{Mudarrisa: Jurnal Kajian Pendidikan Islam, Vol. 10, No. 1, 2018}

objectives, organizing materials, constructing evaluation tools, designing activities, mixing methods and techniques, and exploring resources and instructional media. These seven factors require the skill of teachers so that language learning process is active, innovative, creative, effective, and joyful (Sofan Amri, 2011: 2).

The use of various methods and techniques is expected not to make saturated and monotonous learning atmosphere in presenting the material. The use of innovative techniques and methods can create an effective learning environment. Innovation is an idea, practice, or object considered or accepted as something new by learners in teaching learning process (Daryanto, 2012: 178). Learners in this term are directly involved in absorbing information and reconfirming the recording of information obtained in accordance with the ability of learners themselves (Inten, 2017: 26).

Based on above description, the problem statements presented in this research is how innovative strategy of language skill can be applied in language learning. Teacher's job is very hard. Teacher should be able to teach and introduce students to second language after mother tongue they will learn. Talk and textbook methods are often used by teachers in learning process without any creative and interesting learning presentations that come up in students' minds, so learning process is boring and unattractive (Putri, W., N. \& Nugroho, M., A, 2016: 315). Teacher's ability to create new creations and variations in giving materials also influences the success of teaching and learning activity (Ulin Nuha, 


\section{Mudarrisa: Jurnal Kajian Pendidikan Islam, Vol. 10, No. 1, 2018}

2016: 19). Teacher is the one who is most responsible for the quality of education, because he is the most strategic component in learning process, so many parties put great expectations on teachers in improving the quality of learning (Syamsuddin, 2006: 226).

Madrasa Ibtidaiya (MI) Ma'arif Mangunsari, Sidomukti, Salatiga city is one of the Islamic educational institutions that combines the studies that are general and religious (integrated / interconnection). This Madrasa has a vision of "Intelligent, Religious and having good attitude" and mission of naming the learning model which is "effective, convenient, clear, objective and Islamic" as an effort to improve the quality of competitive graduates and have high selling value. This can be seen from the achievements of learners in each year.

Since 2013, MI Mangunsari no longer prioritizes the quantity in recruitment of students, because the existence of this Madrasa has been owned by the community, therefore, the foundation is thinking to put forward the quality of learning achievement of students at MI Mangunsari. Therefore, teachers are required to be creative, innovative, active and fun in teaching learning process. It is proven that the application of reading corner in the classroom becomes an alternative solution to improve the quality of learners in reading learning process and teacher modeling is an alternative solution of writing activity in class IV B. The measurement is because it has been implemented at that class since 2016 until now.

Teaching requires teacher to work for the success of his students, so students' progress becomes the focus of the teacher's attention. As written 
in hadith H.R. Bukhori, the Messenger of Allah SAW implements teaching learning process that pays more attention to the development of students, so they do not feel bored in learning, as narrated by Ibn Mas'ud that Prophet Muhammad SAW used various methods in giving lessons to avoid boredom (Ritha Asmiati, 2015). It means that to support the success of teaching and learning process, a teacher must have professional competence that is capable of processing materials and able to create an interesting learning process so that students are enthusiastic to catch lessons. He can use methods that are relevant to the material and able to manage the classroom in order to make teaching learning process effective and fun. Based on the background of the problem, researcher is interested in conducting research under the title "The Implementation of Reading Corner and Teacher Modeling in Indonesian Learning through Psycholinguistic Approach in Class IV B of MI Ma'arif Mangunsari Salatiga"

\section{METHODS}

The type of this research is qualitative descriptive research. This research is intended to describe and analyze phenomenon, condition, or other things in which the result is presented in the form of research report (Arikunto, 2010: 4). This research is said as research with descriptive analytical technique because in conducting it the writer did not use statistic number instead of using facts and concrete events, both natural and engineering (Moleong, 2009: 6). 


\section{Mudarrisa: Jurnal Kajian Pendidikan Islam, Vol. 10, No. 1, 2018}

The subjects of this study are students of grade IV B of MI Ma'arif Mangunsari Sidomukti, Salatiga City. This is because Madrasa Ibtidaiya (MI) Ma'arif, Salatiga City is Education Institution that has good reputation and believed by local community and surrounding area to entrust their children to study science, both religion and other general science. The object of this research is the use of reading corner program and teacher modeling for the subjects of Indonesian in 2018 which is applied in semester 1 .

Techniques of collecting data used in this research are: 1) observation, the writer directly observed the teaching learning process through reading corner and teacher modeling; 2 ) interview, conducted to; a) headmaster, as manager as well as the person who is in charge of the whole process of learning; b) teacher, to explore how far reading corner program is applied to support Indonesian subject; c) students, to explore how far reading corner and teacher modeling they can love and apply to support Indonesian subject; 3) Documentation is a method that uses existing data in the form of verbal and nonverbal data. For example the data from students' achievement indexes, letters, diaries, journals, reports, and many more for the completeness of research data (Koentjaraningrat, 1989: 129).

In examining the validity of data, qualitative research method uses different term from that of quantitative research. Test of data validity in qualitative research includes: 1) test of credibility, it is done through extension, observation, improvement of perseverance in research, 
triangulation, discussion with peers, negative case analysis, and member check; 2) transferability, research results may be applied or used in other situations; 3) dependability, it is done by conducting an audit of the entire research process; and 4) conformability, technique of data validity test using inductive analysis (Hadi, 2006: 42).

Before the data is analyzed, it is necessary to verify the collected data. Verification is done by triangulation method. The technique of checking the validity of data is by using other thing out of the collected data. The purpose is to check or compare the validity of the data. After that, the collected and selected data were analyzed to find the meaning behind the data using sources triangulation and methods triangulation (Danim, 2002: 195). Once the data is verified, then the data is analyzed. Technique of analyzing the data in this study is using descriptive analysis, which analyzes critically all the phenomena encountered in the field to draw an objective research conclusion. The analysis is using an inductive method to help understand meaning contained in complex data through the development of themes summarized from crude data (Moloeng, 2009: 298). The steps are to analyze in detail all the phenomena that occur in the field, and then made a generalization by inducing or referring to the theoretical framework that has been presented. 
Mudarrisa: Jurnal Kajian Pendidikan Islam, Vol. 10, No. 1, 2018

\section{RESULTS}

\section{Implementation of Reading Corner and Teacher Modeling Program}

The implementation of reading corner and teacher modeling program is a process to implement policy from political policy into administrative policy. More concisely, it is the development of policies to perfect a program (Afian Nugroho, 2016: 20). Syaffrudin Nurdin (2004: 34) explains that the implementation of reading corner and teacher modeling leads to activity, action, or the existence of a system that is running in a learning process.

Reading Corner is the use of classroom corner as a place to collect books from students in each class. The implementation of reading corner program by fourth grade students of MI Maarif Mangunsari Salatiga is expected to stimulate students in order to be fond of reading and have a good mindset to support Indonesian subject. The use of classroom corner as reading corner also supports school library. In addition to reading, borrowing and exploring the source of knowledge from the school library, students can also take advantage of reading corner in their classes. Books available on shelf of reading corner are students' book collection, so they can exchange with their friends.

After performing flag ceremony, students read the surah of AlQuran, the class is quite for approximately 15 minutes just like an empty class. Teachers and students enjoy reading interesting storybooks. All students are reading in a "Silent Reading" activity that is held 15 minutes before learning process is started. The steps of the program are as follows: 
1) books are provided in the classroom, the result of book brought by students as many as the number of students in the class is stored in the classroom; 2) Every Monday, students and teachers read books according to their interests 15 minutes before the lesson begins; 3) When students finished reading one book, they can be exchange with their friend; 4) The students made summary of the books they have read; 5) One of the students was asked to read the story he had read in front of the class.

Teacher modeling is the activity of teacher of Class IV B to motivate students' reading interest with teacher approach as a direct model in reading corner. The teacher reads silently in the classroom at break time as a direct example. Classes provide books so that students are interested in reading and the school environment is conducive to read. The next day, students are asked to practice reading silently. As the time goes by, this activity becomes a habit for students. Reading habit with reading corner should be encouraged to increase students' reading interest. This is a good way to support the Indonesian learning so that students are able to read fluently.

This class is scheduled to read silently by directly involving the teachers every Monday, starting from 07.30 after performing flag ceremony until 08.00. Teachers enter the class and get involved in reading corner program with books available in the reading corner. In the beginning of the reading corner program by MI Ma'arif Mangunsari Salatiga since 2016 is targeted to improve students' knowledge so that they like to read. This activity is held in the corner of classroom. It is a daily reading activity 
directly conducted by the teacher as a model for students in the classroom. Sometimes it is done every break time and it takes at least 10 minutes, but this does not run well because students and teachers often enjoy the break time freely. Teacher modeling in the classroom of silently reading activity gets a positive value from students, because almost all students follow their teachers in the process reading. The books that have been read are put in the corner of class, in the reading corner.

\section{Reading Skill in Indonesian}

The reading skill in Indonesian subject is complicated, and it involves a lot of things, not only pronunciation but also involving visual, thinking, psycholinguistics, and metacognitive activities (Widiarta Ganing \& Menir, 2014). As a visual process, reading is a process of translating symbols into spoken words (Farida Rahim, 2008: 2). As a process of thinking, reading includes literacy comprehension, interpretation, critical reading, and creative comprehension activities. Word recognition can be in the form of reading words by using dictionary (Imam Asrori, 2016).

Reading can also be interpreted as a method that we use to communicate with ourselves and sometimes with others, that is communicating the meaning contained on the written symbols (Tarigan, 1979: 8). Reading is important in learning activities, because by reading we can get a lot of information; even by reading we can reach the past and the future. Reading is an activity to gain meaning from what is written in the text (Tarigan, 1979: 246). According to Haris in Mulyono (1999: 201) 
states that there are five stages of reading development, namely: 1) reading readiness; 2) Reading the beginning; 3) Fast reading skill; 4) broad reading, and 5) real reading.

The development stage of reading for upper class students of elementary level is in the skill of fast reading, broad reading and real reading. This activity can be done by reading the story books to stimulate children's reading interest. The followings are some techniques of reading skill that can be done by teachers: 1) Motivation that is formed through Modeling in the process of reading; 2) teacher oriented; 3) the use of IT (information and technology), namely the process of reading by utilizing the existence of technology as a substitute for non-electronic books (Pratiwi \& Ariawan, 2017).

Learning to read can use a process approach. The process in question is a process of reading. Learning to read using a process approach can improve students' reading skill. It has advantage if reading process is exhibited in front of students. In second stage of reading process the students read the books or reading as a whole. There are five kinds of reading models (Tomkins \& Hoskisson, 1995) in Djumingin (2009: 88), as follows; reading aloud, shared reading, buddy reading, guided reading, and independent reading.

\section{The Ultimate Goal of Reading Corner Habit}

The ultimate goal of a reading corner habit is to find and get information, including content, to understand the meaning of reading. The meaning 
contained in reading is closely related to the goal, or our intense in reading (Tarigan, 1979: 9). In addition, the purpose of reading corner habit includes several things, namely: 1) raising the pleasure to read; 2) perfecting in the process of reading done loudly; 3) Using a specific strategy; 4) Updating knowledge with a particular topic; 5) Linking new information with information already known; 6) Obtaining information for oral or written reports; 7) Confirming or rejecting prediction; 8) Displaying an experiment or applying information obtained from a text in some other ways and learn them.

The aspects of reading in activity of reading corner are: 1) Sensory aspect, that is the ability to understand written symbols; 2) Affective aspects or aspects of emotion are aspects that are gained from personal experience, attitudes of parents, teachers, and groups that support the activities students like; 3) The schematic aspect is one of important aspects that determines the success of reading. Schemata is a structure of abstract knowledge that is stored hierarchically in the brain; 4) Perceptual aspect is the process of associating meaning and interpretation based on experience about the stimulus or symbol, and the response that connects meaning with the stimulus or the symbol. (Alfian Handina, 2016). Reading activity consists of two components, namely: a) reading process, and b) reading product (Djumingin, 2009).

The Reading Process is to convey that it consists of 9 aspects, namely sensory, perceptual, sequence, experience, thought, learning, association, attitude, and idea. The visual sensory process according to 
Farida Rahim (2008: 12) is obtained by disclosure of graphic symbols through the sense of sight, so the children learn to visually distinguish graphic symbols used to present oral materials. Perceptual activity is a way to know a word done by teachers to students to get meaning based on past experience. The sequence aspect is an activity of following a linear arrangement of writing, which generally appears in one page from left to right or from top to bottom.

Experience is an important aspect in reading process. Teachers can guide students to improve thinking skill through reading by providing questions that might help improve students' thinking ability. The given questions are not solely questions that produce answers in the form of facts. The next reading process is the aspect of association by understanding the relationship between symbols and sound of language and its meaning (Farida Rahim, 2008: 12-13). Motivation and pleasure to read help students focus on reading. Meaning is built on the text they read, but it is not entirely encountered in the text. The reader will produce a different meaning from the same text if the experience and affective reactions of the reader are different (Inten, 2017: 26).

The second reading activity component is reading product. Reading product is a communication of thought and emotion between the author and the reader. Communication can also occur from the reader's construction through the integration of knowledge that readers already have with the information presented in the text. Communication in reading depends on the understanding that is influenced by all aspects of 
reading process. Henry Guntur Tarigan (1985: 11) explains that there are two important aspects of reading, namely mechanical skill and understanding skill. Mechanical skill is a skill that is available in a lower position. This aspect, according to Henry Guntur Tarigan (1985: 11) includes the introduction of letters, linguistic elements (phoneme, word, phrase, clause pattern, sentence, etc.), the introduction of spelling and sound (the ability to spell written materials), and speed (Tarigan, 1985: 12).

\section{Psycholinguistic Approach in Learning Process}

Psycholinguistics is a science that describes the psychological processes that occur when a person produces a sentence and understand the sentences he hear when communicating and how the ability of language is obtained by humans (Simanjuntak, 1987: 1). Aitchison (1984) limits psycholinguistics as a study of language and thought. Psycholinguistics is a field of study that connects psychology with linguistics. The main goal of a psycholinguist is to discover the structure and process that underlie human ability to speak and understand the language. Psycholinguists are not interested in language interaction among the speakers of language, what they do is to explore what happens when people speaks the language (Lisnawati, I., 2008: 34-35).

Dealing with psycholinguistics, teachers can apply the approach in language teaching by looking at the situation of students, for example behavioral or mental approach. All efforts in applying the approach can 


\section{Mudarrisa: Jurnal Kajian Pendidikan Islam, Vol. 10, No. 1, 2018}

achieve optimal goals that students can speak well and correctly. Psycholinguistics that contains several approaches might help teachers make a good lesson plan for each meeting (Siregar, 2013: 40). So the final purpose of teachers is to design language teaching in such a way. Based on the issues especially in terms of psycholinguistics teaching and learning process that they have significant implication (Djiwandono, 2008: 86).

Psycholinguistics is implemented to subjects written in curriculum, for example the subjects of listening and speaking, which one should be preceded. Obviously, the listening aspect should be preceded, and then the second aspect is speaking when viewed from psycholinguistics perspective. Because when the baby is born, the language skill in listening aspect takes more time. So, listening is the first manifestation of language skill. The use of varied method and technique is done in order not to make teachers saturated and monotonous in presenting the materials. The use of innovative techniques and methods can create a conducive learning situation (Umar Mansyur, 2016).

Teachers' work is guiding and confirming meaningful activities. Students are given opportunity to develop their creativity, they can develop their potential (Putri, W., N. \& Nugroho, M., A, 2016: 318). With regard to psycholinguistics, teachers should consider the maturity level of students with relevant theories. Teachers' job is exploring the innate potential, both in the classroom and outside the classroom, just like when doing a tour work. 
The selection of material and compilation of syllabus in Psycholinguistics done by fourth grade teacher of MI Maarif Mangunsari is made by considering the level of difficulty, the purpose of learning, and time required. This formula provides illustration that psycholinguistics can be applied in the selection of material, by considering several aspects such as: 1) the level of difficulty; 2) the material can be taught; 3) age of students; 4) the attitude of students; and 5) usefulness.

Psycholinguistics in assessment is used to measure one's skill in a range of instructional program based on the objectives that will be achieved as a tool used to assess the results of conducted test (Muh Busro, 2016). In this case, psycholinguistics plays an important role in the assessment by considering some aspects such as; 1) learners that include age, background, and socioeconomic; 2) test material that will be given to students; and 3) when the assessment will be conducted, for example tentative assessment process is undertaken after studying one unit of learning, or after the entire unit is learned, or after the students are tired. So based on the assessed aspect, not only cognitive aspect that gets a large portion of the psycholinguistic approach, but it also includes knowledge, understanding, application, analysis, synthesis, and evaluation. The teachers at MI Maarif Mangunsari must perform teaching program from things that have been described neatly before, either oral or written. 


\section{DISCUSSION}

Based on the results of description of the data about the implementation of reading corner and teacher modeling program in customizing language learning in class IV B, the writer analyzed the results of observation that the implementation of reading corner and teacher modeling program has very significant impact on learning process in the classroom, it also influences the capacity to increase knowledge and students' academic ability of class IV $\mathrm{B}$ in teaching learning process. This is in line with the vision and mission of the Ministry of Education and Culture that proclaims the movement of character growth through a series of noncurricular activities, namely a series of daily activities which is obligatory or optional. One of the obligatory activities at school before starting learning is reading non-textbooks. This is in line with reading corner and teacher modeling program that have been declared as internal policy of Madrasa Ibtidaiya mangunsari Salatiga through headmaster and implemented by class teachers in each class.

The steps done by the fourth grade teacher to implement reading corner and teacher modeling program are: 1) telling students about the importance of reading for intelligence; 2) creating worksheets to trigger students' reading process; 3) guiding students to review the contents of the textbook, especially on Indonesian learning materials; 4) giving positive examples, being role model for students by spending free time to read; 5) familiarizing students to read the material that will be discussed in the class; 6) Giving task to resume Indonesian book and materials already 
explained once a week, and reading the results in front of the class; 7) Inviting students to search for other learning resources such as internet, documentaries, magazines, newspapers and news. Then they write and read out the results in front of the class. The students like this process so much. And the result of interview with some students showed that learning is not boring, varied, and can obtain information which is not written in textbooks.

\section{Implementation Process of Reading Corner in Class}

Based on the result of observation, the reading corner program in class IV B has a habit that is included in school lesson schedule. It is written in schedule that reading habit is held for about 15 minutes before teaching and learning activity is begun. The activity is started with the Al-Quran and book collection of reading corner from each student. The purpose of this activity is that students will get knowledge through textbooks that have been read. Reading al-Qur'an aims at instilling religious character so that students' religious knowledge improves (the results of interview with principal and teachers at MI Maarif Mangunsari Salatiga)

Based on the results of research observations on students' affective aspects conducted for about six months, the writer sees the developments experienced by students as follows; 1) students have high motivation and awareness to read diligently in their classrooms; 2) creating a conducive environment for students to learn something through reading, so children who do not like to read are influenced by the environment although they 


\section{Mudarrisa: Jurnal Kajian Pendidikan Islam, Vol. 10, No. 1, 2018}

just open and look at the book; 3) the way students learn is open, and they don't rely on their teacher to get knowledge; 4) the emergence of interest to discuss and ask the teacher information that learners get in reading; 5) the emergence of courage of students in conveying idea of the results of understanding of the textbooks that they have read; 6) there is a feedback from the process and write it as the answer to the questions; 7) students' vocabulary mastery is getting better; 8) having an influence on students' learning motivation, and it has implications to improve students' academic ability.

This phenomenon cannot be separated from the strategy undertaken by teacher as teacher modeling. This is also supported by appropriate infrastructure of reading corner program. In addition, a good speaking skill and being diligent in reading, students get significant improvement in knowledge from their reading experience. Students are also able to apply it in their daily life at school, especially Indonesian lesson. The existence of reading corner and teacher modeling in reading activity encourages students to learn Indonesian happily. The students of class IV B really enjoy learning Indonesian. Dealing with psycholinguistic approach, teachers can apply it in language teaching by looking at the situation of students, for example approach that is related to certain theory, such as behavioral or mental approach. All efforts in applying this approach is to achieve optimal goals so that students can speak well and correctly. Psycholinguistics that contains several approaches might help teachers 
make a good lesson plan for each meeting. As a result, the ultimate goal of a teacher in learning process can run as expected.

\section{CONCLUSION}

Language as a means of communication plays an important role in everyday human life, which is used to express idea, thought, feeling or information to others, either oral or written. There are 4 components of language skill, namely listening, speaking, reading, and writing. Therefore, in teaching and learning process must use a good strategy so that learning process is interactive and interesting. Program of reading corner and teacher modeling through psycholinguistic approach is applied to support the process of language learning so that the students are highly motivated to read, write, listen and speak, which has implications to create a good teaching and learning process, curriculum which is appropriate with the changes of human dimension, appropriate lesson plan, materials and syllabus for students, as well as performing appropriate assessment. This is a good example that other schools can practice to develop students' intellectual capacity of language and character through a special time allocation as a form of habituation for students, eventhough it is only 15 minutes, yet the activity can encourage students to make reading as a need.

\section{REFERENCES}

Depdiknas, Peraturan. Menteri Pendidikan Nasional. Republik Indonesia Nomor 22 Tahun 2006. Tentang. Standar Isi. Jakarta: Depdiknas. 
Ahmad, S. (2011). Perkembangan Bahasa Anak Prasekolah. Jakarta: PT. Kencana Prenada.

Ampuni, S. (1998). Proses Kognitif Dalam Pemahaman Bacaan. Journal Psikologi. 6 (2). 16-26.

Amri, S. (2011). Paikem Gembrot Sebuah Analisis Teoritis dan Praktis. Jakarta: Prestasi Pustaka.

Arikunto, S. (2010). Prosedur Penelitian: Suatu Pendekatan Praktik. Jakarta: PT. Rhineka Cipta.

Asrori, I. (2016).Strategi Pembelajar Indonesia Mengidentifikasi Makna Kata Bahasa Dalam Konteks Kalimat Wacana Geografi. Journal Arabi. 1 (2). 11-23.

Batubara, H. H. \& Ariani, D. N. (2018). Penyelenggaraan Bimbingan dan Konseling di Sekolah Dasar. Jurnal Pendidikan; Teori, Penelitian dan Pengembangan. 3 (4). 447-452.

Busro, M. (2016). Kajian Dalam Psikolinguistik, Perangkat Penelitian, Strategi, dan Penggunaan Metode Penelitian. Journal Al Hikmah. 6 (2). 209-218.

Chaer, A. \& Agustina, L. (2010). Sosiolinguistik: Perkenalan Awal. Jakarta: PT. Rineka Cipta.

Danim, S. (2002). Menjadi Peneliti Kualitatif, Bandung: Pustaka Setia.

Daryanto. (2012). Model Pembelajaran Inovatif. Yogyakarta: Gava Media.

Djiwandono, S. (2008). Tes Bahasa Pegangan Bagi Pengajar Bahasa. Jakarta: PT. Indeks.

Djumingin. Sulastriningsih \& Syamsudduha. (2009). Perencanaan Pembelajaran Bahasa dan Sastra Indonesia. Makassar: Badan Penerbit UNM

Farboy, S. (2009). Penerapan Metode Cooperative Integrated Reading And Composition (CIRC) Untuk Meningkatkan Kemampuan Menemukan Gagasan Utama Sebuah Teks Pada Siswa Kelas VII di SMP Negeri 3 Batu. Journal Artikulasi. 7 (1). 415-431.

Hadi, S. (2006). Metodologis Reseach. Jakarta: Andi Offset.

Inten, D., N. (2017). Role Of the Family Toward Early Literacy of The Children. Jurnal Pendidikan Anak Usia DIni, 1 (1). 23-33.

Koentjaraningrat. (1989). Metode-Metode Penelitian Masyarakat. Jakarta: Gramedia. 
Langi, A. Tahir, M., \& Idris. (2017). Peningkatan Kemampuan Membaca Dan Menulis Dengan Menggunakan Kartu Huruf di Kelas I SDN 2 Wombo, Jurnal Kreatif Tadulako. 4 (8). 88-102.

Lisnawati, I. (2008). Psikolinguistik dalam Pembelajaran Bahasa. Dalam Educare: Jurnal Pendidikan dan Budaya. 6 (1). 31-44.

Mansyur, U. (2016). Inovasi Pembelajaran Bahasa Indonesia Melalui Pendekatan Proses. Journal Retorika. 9 (2). 90-163.

Moleong, L., J. (2009). Metode Penelitian Kualitatif, Bandung: PT. Remaja Rosdakarya.

Muslih, M. (2009). Melaksanakan PTK itu Mudah; Classroom Action Research. Jakarta: Bumi Aksara.

Mustikowati, D. Wijayanti, E. \& Darmanto, J. (2016) Meningkatkan Semangat Membaca Dan Menulis Siswa Sekolah Dasar Dengan Permainan Kata Bersambut. Briliant: Jurnal Riset dan Konseptual. 1 (1). 39-42.

Nugroho, A. H., Puspitasari, R. \& Puspitasari, E. (2016). Implementasi gemar membaca melalui program pojok baca dalam mata pelajaran IPS pada siswa kelas VIII di SMPN 2 Sumber, Jurnal Edueksos. 5 (2). 187-206.

Nurdin, S. (2004). Guru Profesional dan Implementasi Kurikulum. Jakarta: Intermasa.

Putri, W.,N. \& Nugroho, M.,A. (2016), Strategi Pengembangan Profesionalisme Tenaga Pendidik di Madrasa. Mudarrisa; Jurnal Kajian Pendidikan Islam. 8 (2). 313-340.

Pratiwi, I. M. \& Ariawan, V. A. N. (2017). Analisis Kesulitan Siswa dalam Membaca Permulaan di Kelas Satu Sekolah Dasar. Jurnal Sekolah Dasar. 26 (1). 69-76.

Rahim, F. (2008). Pengajaran Membaca di Sekolah Dasar. Jakarta: Bumi Aksara.

Siregar. Y. (2013). Kompetensi Guru Dalam Bidang Strategi Perencanaan Dan Pembelajaran Matematika. Journal Formatif. 3 (1). 39-48.

Sugiyono. (2009). Metode Penelitian Pendidikan: Pendekatan, Kuantitatif, Kualitatif, dan R $\mathcal{E}$ D. Bandung: Alfabeta. 
Mudarrisa: Jurnal Kajian Pendidikan Islam, Vol. 10, No. 1, 2018

Sulasih, E. S. (2016). Pengaruh Minat Membaca Karya Sastra Kreativitas Terhadap Keterampilan Menulis Novel. Journal Pujangga. 2 (2). 80 93.

Syamsuddin. (2006). Metode Penelitian Pendidikan Bahasa. Bandung: PT. Remaja Rosda Karya

Tarigan, H., G. (1979). Membaca sebagai suatu keterampilan berbahasa. Bandung: PT. Angkasa.

Widiarta, I. W. Ganing, N. \& Meter I. G. (2014). Pengaruh Pendekatan Quantum Reading Terhadap Keterampilan Membaca Dalam Pelajaran Bahasa Indonesia. Jurnal Mimbar PGSD. 2 (1). 2014. 